\title{
FIRM VALUATION - NEW METHODOLOGICAL APPROACH
}

\author{
Ivo Šperanda* \\ Keywords: valuation; value; DCF; CCF; method; investment; financial statement \\ JEL:
}

\begin{abstract}
Valuating theory and practice recognize numerous methods of firm valuation, but one of the most frequent one is DCF method of valuation. Mentioned method is based upon two essential attributes: recognizing time value of money and calculating firm value as a sum of presumptive future net incomes discounted by the discretionary hurdle rate. On the opposite, the CCF (Compounded Cash Flow) method is based upon historical Financial Statements and historical data as well as reliable and publicly published data used for revising certain data in Balance Sheets and PELLs and deflating the Cash Flow. This method, basically leaned on real and actual data, assures valuation much more reliable and positive.
\end{abstract}

*University of Dubrovnik - Department of Economics and Business Economics, Lapadska obala 7, 20000 Dubrovnik, mail: ivo.speranda@unidu.hr 


\section{Introduction}

Firm valuation in international business has been one of the crucial issues of microeconomic financial analysis for few decades. It doesn't only imply valuating certain firms but different investments as well.

Considering frequent usage of this term it is necessary to clearly define it. The statement in B. Graham's capital work "The Intelligent Investor" - An investment operation is one which, upon thorough analysis, promises safety of principal and an adequate return - (Graham, 2006, 27) would be the most appropriate, according to the author of this paper.

The most common method of valuation is certainly the DCF (Discounted Cash Flow) with all its numerous variants. The main feature of this dynamic method is using the concept of time value of money and basing the final value on present value of future cash flows.

Other common methods (accounting, enterprise multiple and similar ones) are so called static methods and are mainly used as supplement or control of DCF method.

The main disadvantage of the DCF method, which has been seriously criticized for the last few years, is that it relies on the future business events and cash flows forecasts which are based on historical data and certain assumptions. CCF method (Compounded Cash Flow) uses new methodology approach by using historical data of firm's balance sheet which is evaluated in certain period of time. Balance sheet information are adjusted according to reliable and available information (inflation rate, market price and similar), supposing the concept business as usual.

In other words, DCF method is based on the future income projection decreased for arbitrary discount rate. Since CCF is a posteriori method and operates with historical data, those data are not discounted but moreover, they are compounded at the most logical rate, Internal Rate of Return and at its variants.

This paper brings all advantages of the CCF method by which certain disadvantages of other valuation methods (such as quality of entry parameters and 
their manipulation) are eliminated. Theoretically, this paper demonstrates the $\mathrm{CCF}$ as a model-based procedure, while in practice it serves well for valuation of investments in different business actions.

\section{SHORT OVERVIEW OF MOST COMMONLY USED VALUATION METHODS}

Three firm value methods, each based on the specific problem approach, have lately distinguished in business practice.

Accounting or Cost Based Method is considered the easiest to apply and is based on firm's balance sheet which is valuated along with additional modifications of assets and liquidation costs liabilities (asset sale costs, debts collection, obligations towards the employees, providers, depreciation adjustments and similar). Balance sheet is examined and adjusted to the actual situation, as International accounting standards imply.

Firms with greater physical assets, i.e. capital intensive (factories, hotels and similar) are more protected when using this method, i.e. are more valuable than firms having so called intangible assets, meaning non-material assets.

After the valuation and revision of all accounting entries, all liabilities are deducted from total assets and book value is gained.

$$
\text { TotalAssets }- \text { TotalLiabilities }=\text { Firm/sNetValue }
$$

Thus calculated firm value very often represents the lowest value under which a firm should not be sold.

The advantages of this method are simplicity, speed, transparency, foundation on balance sheet information, and the convenience to evaluate those firms which have just started doing business, i.e. are in the early development phase.

The disadvantage of the method is that it is very static. The valuation is performed on a specific date without considering prior business events or 
business potentials. In other words, only the firm's asset is evaluated and not firm's business and its possible effects.

Market Method or Enterprise Multiple is very popular method due to its simplicity. P/E (Price / Earnings Ratio) is simply multiplied by firm's earnings. This method is based on the assumption that it is possible to find firms whose shares are listed on the stock market and that are similar to firm which is being evaluated, and to determine adequate multipliers for certain firm, bearing in mind the differences between the comparable firm and the one being evaluated. Besides simple and fast value calculation, other advantages would be the simple presentation of gained values and finally the fact that they reflect current market situation. However, the flaws or this value method outnumber its advantages, the main flaw being over simplifying and neglecting key indicators of every firm's business (sources and generators of income, expenditure and profit). Such calculated value (regardless to multipliers type) is approximate and very often gives wrong valuation and enables at the same time information manipulation.

DCF (Discounted Cash Flow) or Income Value Approach ${ }^{1}$ is basic valuation model which calculates discounted future values of expected cash flows; calculated as

$$
D C F=\sum_{t=1}^{n} C F_{t}\left[\frac{1}{(1+k)}\right]^{t}
$$

Where:

$\mathrm{DCF}=$ discounted cash flow

$\mathrm{CFt}=$ cash flow for the year $\mathrm{t}$

$\mathrm{k}=$ discount rate

$\mathrm{n}=$ number of periods

In difference to models of multipliers, Discounted Cash Flow method is based on the firm's business. During valuation it is important to consider basic firm's characteristics and, at the same time to understand type of business. Finally, this method evaluates business, and not only the assets.

The possibility to manipulate entry information is rather big (and present), even with concrete entry information and parameters. The valuation is based upon the projected sizes founded on historical information and discounted at 
rather arbitrary discount rate, especially in Croatia where correct rate calculation of return according to CAPM (Capital Asset Pricing Model) is very doubtful. ${ }^{2}$

This model determines an expected return rate $\mathrm{E}(\mathrm{R})$ at certain asset as a function of included risks.

$$
E(R)=R F R+(E R P \cdot \beta)+\alpha
$$

Where:

$\mathrm{E}(\mathrm{R})=$ expected rate of return

$\mathrm{RFR}=$ risk free investment return

$\mathrm{ERP}=$ estimated market return

$\beta=$ measure of market volatility (systematic risk)

$\alpha=$ firm's volatility (unsystematic risk)

\section{SHORT OVERVIEW OF MOST COMMONLY USED VALUATION METHODS}

Valuation concept i.e. different methodology approach to firm valuation which this works suggests and describes in short, is based on the DCF valuation concept, simultaneously aiming at eliminating the disadvantages of the method, firstly the possibility of manipulating with entry information for valuation (income, expenditure, profit and similar) and manipulating with arbitrary (regardless to skillfully disguised complicated math formulas) determination of discounted rate. By looking at the relation number 3 , it is evident that the costs of owner's equity or discounted rate are composed of rate of return to risk free (although such literally doesn't exist) asset which itself is composed of inflation rate and real rate of return. In AAA credit rating countries (USA, Great Britain, France...), T-Bonds have risk-free rate of return. In other countries with lower credit rating (Honduras, Bulgaria, Croatia and similar), T-bonds

\footnotetext{
${ }^{2}$ Since CAMP and WACC are widely used methods for determining discount rate, and volatility and industrial branches of the firm ( $\beta$ and $\alpha$ ) are needed for calculation, which has been impossible in Croatia so far.
} 
have Country Risk Premium which must be considered as well. In the table number 1 , there is a comparable overview of certain countries, including Croatia (Baa3).

TABLE 1: Certain Countries Rating Overview

\begin{tabular}{|c|c|c|c|}
\hline Country & $\begin{array}{l}\text { Long-Term } \\
\text { Rating }\end{array}$ & $\begin{array}{c}\text { Typical Interest } \\
\text { Rate }\end{array}$ & $\begin{array}{c}\text { Country Risk } \\
\text { Premium }\end{array}$ \\
\hline United States & Aaa & $6.10 \%$ & $0.00 \%$ \\
\hline Andorra & $\mathrm{Aa} 2$ & $6.75 \%$ & $0.65 \%$ \\
\hline Argentina & $\mathrm{Ba} 3$ & $10.10 \%$ & $4.00 \%$ \\
\hline Australia & $\mathrm{Aa} 2$ & $6.75 \%$ & $0.65 \%$ \\
\hline Austria & Aaa & $6.10 \%$ & $0.00 \%$ \\
\hline Belgium & Aaa & $6.10 \%$ & $0.00 \%$ \\
\hline Belize & $\mathrm{Ba} 2$ & $9.10 \%$ & $3.00 \%$ \\
\hline Bolivia & B1 & $10.60 \%$ & $4.50 \%$ \\
\hline Brazil & B2 & $11.60 \%$ & $5.50 \%$ \\
\hline Bulgaria & B2 & $11.60 \%$ & $5.50 \%$ \\
\hline Canada & $\mathrm{Aa} 2$ & $6.75 \%$ & $0.65 \%$ \\
\hline Chile & Baal & $7.30 \%$ & $1.20 \%$ \\
\hline China & $\mathrm{A} 3$ & $7.05 \%$ & $0.95 \%$ \\
\hline Colombia & $\mathrm{Baa} 3$ & $7.55 \%$ & $1.45 \%$ \\
\hline Costa Rica & Bal & $8.60 \%$ & $2.50 \%$ \\
\hline Croatia & Baa3 & $7.55 \%$ & $1.45 \%$ \\
\hline Cyprus & $\mathrm{A} 2$ & $7.00 \%$ & $0.90 \%$ \\
\hline Czech Republic & Baal & $7.30 \%$ & $1.20 \%$ \\
\hline Denmark & Aal & $6.70 \%$ & $0.60 \%$ \\
\hline Dominican Republic & B1 & $10.60 \%$ & $4.50 \%$ \\
\hline Ecuador & B3 & $12.60 \%$ & $6.50 \%$ \\
\hline Estonia & Baal & $7.30 \%$ & $1.20 \%$ \\
\hline Finland & Aaa & $6.10 \%$ & $0.00 \%$ \\
\hline France & Aaa & $6.10 \%$ & $0.00 \%$ \\
\hline Germany & Aaa & $6.10 \%$ & $0.00 \%$ \\
\hline Greece & Baal & $7.30 \%$ & $1.20 \%$ \\
\hline Guatemala & $\mathrm{Ba} 2$ & $9.10 \%$ & $3.00 \%$ \\
\hline Guernsey & Aaa & $6.10 \%$ & $0.00 \%$ \\
\hline Honduras & B2 & $11.60 \%$ & $5.50 \%$ \\
\hline Hong Kong & $\mathrm{A} 3$ & $7.05 \%$ & $0.95 \%$ \\
\hline Hungary & $\mathrm{Baa} 2$ & $7.40 \%$ & $1.30 \%$ \\
\hline Iceland & $\mathrm{Aa} 3$ & $6.80 \%$ & $0.70 \%$ \\
\hline Liechtenstein & Aaa & $6.10 \%$ & $0.00 \%$ \\
\hline Lithuania & Bal & $8.60 \%$ & $2.50 \%$ \\
\hline Luxembourg & Aaa & $6.10 \%$ & $0.00 \%$ \\
\hline Slovenia & A3 & $7.05 \%$ & $0.95 \%$ \\
\hline
\end{tabular}

Source: www.sjsu.edu/faculty/watkins/countryrisk.htm 
Abbreviation ERP stands for extra return; it is actually the rate that certain investor demands in order to invest into stocks and not in T-bonds, enlarged for systematic risk (ß) of firm's economic sector. Finally, there is ? representing the risk measure (volatility) of certain firm. So, future profits, resulting from the cost / income difference and based on firm's business plans for the next 3, 5, 10 years (being the plans made by the very management of the firm) are discounted by the rate (gained by the previously described procedure). The investor is now buying firm's value, along with presumptive future profits on which the valuation was based.

The concept of the new approach (method):

1. (a) i. A. Usage of historically (relatively) reliable information from the firm's financial documents in certain past period of time $(\mathrm{n}=3,5,10,15 \ldots$ years $)$.

2. Income and similar categories from the financial statements are discounted to present value at the rate equal to internal rate of return (IRR) of the firm realized in the observed period of time (Fig. 1).

3. All information are previously deflated by using official inflation rates (provided by the Croatian National Bank, Croatian Bureau of Statistics or similar sources).

4. Business as usual is starting point, and so called residual value is not taken into account.

It is completely clear that the concept is based on actual, logical and easily available information, making this model reliable in terms of evaluation. 
FIGURE: 1 Compounted Flow

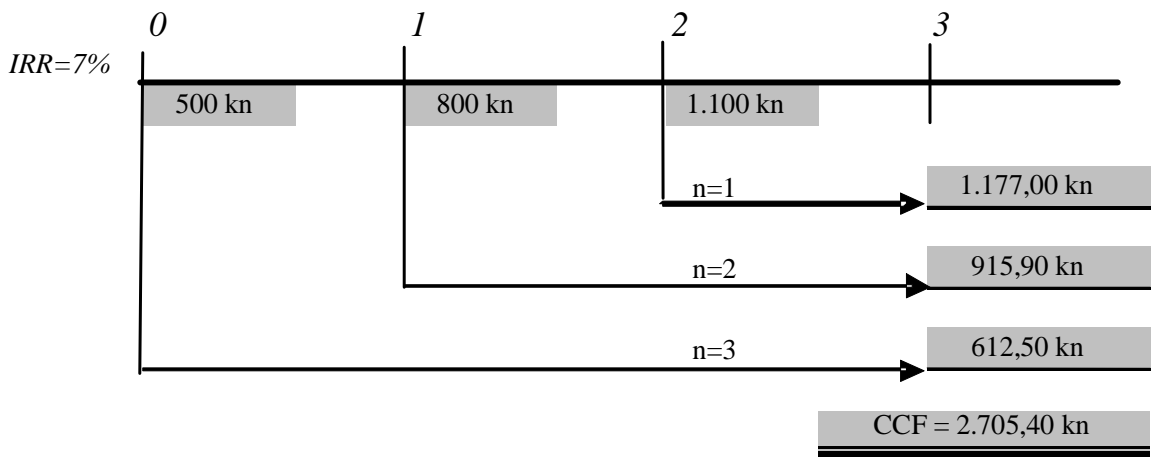

Source: Vidučić Lj.: "Financijski menadžment"(II edition )- RRIF Zagreb,2001. p.41.

TABLE 2. Inflation Rates in Croatia

\begin{tabular}{cr}
\hline \hline Year & Inflation rate \\
\hline 1997 & $2.50 \%$ \\
1998 & $5.20 \%$ \\
1999 & $2.80 \%$ \\
2000 & $3.30 \%$ \\
2001 & $1.40 \%$ \\
2002 & $1.10 \%$ \\
2003 & $1.10 \%$ \\
2004 & $2.30 \%$ \\
2005 & $2.90 \%$ \\
2006 & $2.40 \%$ \\
2007 & $4.70 \%$ \\
2008 & $4.50 \%$ \\
2009 & $0.30 \%$ \\
\hline \hline
\end{tabular}

Source: www.hnb.hr/public/prezent/spf-cro-ppt

Ivo Speranda - FIRM VALUATION - NEW METHODOLOGICAL 
Mathematical illustration of the proposed model is ${ }^{3}$ :

$$
C C F=\sum_{t=1}^{n} C F_{t}(1+k)^{n-t}
$$

Where:

$\mathrm{CCF}=$ compounded cash flows

$\mathrm{CFt}=$ cash flow in the year $\mathrm{t}$

$\mathrm{k}=$ internal rate of return, i.e. real rate of return

$\mathrm{n}=$ number of periods

In this model, CCF equals the firm's value obtained as a sum of historical, revised cash flow income, gross income and similar categories in „n" periods and compounded at the IRR in final observed period. Appraisal's choice of category (profit, gross profit, FCF, EBIT, NOPAT...) differs from case to case provided that thorough explanation about chosen category is given.

Proposed average compound rate is IRR which should be spread to so-called TRR (True Rate of Return) as it contains calculated reinvestment rate. ${ }^{4}$

It is in fact often considered that the net profit, for the given period of time, is reinvested at rate defined by the discount rate. This assumption naturally does not need to be true and the reinvestment rate can be different from the discount rate.

As initial investment is required for the TRR calculation, when evaluating firm's business it is advisable to use firm's capital value, i.e. shareholder's equity; relation of TRR is hence calculated:

$$
T R R=\sqrt[n]{\frac{\sum(C F) \cdot(1+r R)^{n-i}}{\sum K i(1+r)^{-i}}}-1
$$

Where:

$\mathrm{TRR}=$ true rate of return

$\mathrm{rR}=$ reinvestment rate

$\mathrm{Ki}=$ investment (capital)

\footnotetext{
${ }^{3}$ Designation of the CCF model (Compounded Cash Flow) is determined by the analogy of the DCF (Discounted Cash Flow)

${ }^{4}$ Consult : Nušinović M.: "Planiranje investicijskih projekata u funkciji optimizacije društveno-ekonomskog razvoja "-Ekonomski institut-Zagreb, 1989. pp.144-146.
} 
$\mathrm{n}=$ number of periods

$\mathrm{r}=$ discount rate

When determining IRR, the problem of multiple internal rate of return might appear. There are many approaches and possibilities of resolving such a problem. ${ }^{5}$

\section{COMPARABLE EVALUATIONS}

By one concrete example comparable evaluations will demonstrate the advantages of the proposed concept (and obstacles of classic DCF model) and a calculation of CCF.

An example ${ }^{6}$ of accounting or cost-based method calculation would be as follows in the table 3 .

\footnotetext{
${ }^{5}$ Consult :Martić Lj.: " Kvantitativne metode za financijske i računovodstvene analize"Informator, Zagreb,1980. pp.25-28. ; also see: www.stern.nyu.edu/-adamodar/pc/cf2Eil

${ }^{6}$ Information for this example was taken from the real industrial firm valuation from 1999.
} 
TABLE 3 : Book Value as of December 31st, 1998

\begin{tabular}{|c|c|c|}
\hline No. & Description & $\begin{array}{l}\text { Revised amount } \\
(\mathrm{kn})\end{array}$ \\
\hline & ASSETS & \\
\hline & Long term assets & \\
\hline 1 & Land and forests & 2.406 .346 \\
\hline 2 & Buildings & 25.791 .243 \\
\hline 3 & Plant and equipment & 6.701 .847 \\
\hline 4 & Physical assets in preparation & 5.305 .702 \\
\hline \multirow[t]{2}{*}{5} & Total & 40.205 .138 \\
\hline & Provisions & \\
\hline 6 & Raw and other materials & 5.242 .781 \\
\hline 7 & Work in progress & 956.572 \\
\hline 8 & Finished goods & 9.987 .130 \\
\hline \multirow[t]{3}{*}{9} & Advance payments & 86.148 \\
\hline & Total & $\underline{16.272 .631}$ \\
\hline & Receivables & \\
\hline 10 & Trade receivables & 6.732 .527 \\
\hline 11 & Receivables from employees & 14.272 \\
\hline 12 & Receivables from government institutions & 207.991 \\
\hline \multirow[t]{3}{*}{13} & Other receivables & 321.294 \\
\hline & Total & 7.276 .084 \\
\hline & Financial assets & \\
\hline 14 & Securities & 197.078 \\
\hline 15 & Cash in bank and on hand & 4.210 .481 \\
\hline & Total & 4.407 .559 \\
\hline $\mathbf{A}$ & TOTAL ASSETS VALUE & 68.161 .412 \\
\hline 16 & Lease liabilities & 2.971 .257 \\
\hline 17 & Liabilities for advances, deposits and guarantees & 7.922 \\
\hline 18 & Trade payables & 2.460 .067 \\
\hline 19 & Liabilities toward employees & 628.012 \\
\hline 20 & Liabilities for taxes, contributions and similar & 442.285 \\
\hline 21 & Liabilities based on share in result & 742.133 \\
\hline 22 & Other current liabilities & 112.848 \\
\hline 23 & Accrued payment of expenses & 213.940 \\
\hline B & TOTAL LIABILITIES & 7.578.464 \\
\hline $\mathbf{C}$ & FIRM'S BOOK VALUE (A-B) & 60.582 .948 \\
\hline
\end{tabular}

Source: Authors calculation

Book value is obtained by having used the relation (1), as shown in the table 3 .

Market method, i.e. evaluation method based on usage of multipliers will be left out in this work for two reasons: this method has a controlling character 
due to its approximation and short horizon. Since this concrete case was dealing with the Croatian firm, it was not possible to find adequate multipliers for valid valuation.

For the DCF evaluation method it is necessary to calculate the Profit and Loss Account for the period of five years.

TABLE 4: Profit and Loss Account for the Period of 1999. - 2003.

\begin{tabular}{|c|c|c|c|c|c|}
\hline Item / Year & 1999. & 2000. & 2001. & 2002. & 2003. \\
\hline 1.Income & 27.295 .843 & 25.564 .036 & 23.092 .919 & 21.651 .046 & 20.849 .101 \\
\hline 2. Operating cost $(2.1 .+2.2)$. & 33.249 .027 & 32.457 .375 & 31.297 .823 & 30.763 .988 & 30.394 .678 \\
\hline 2.1. Production costs $(2.1 .1 .2 .1 .3)$. & 33.249 .027 & 32.457 .375 & 31.297 .823 & 30.763 .988 & 30.394 .678 \\
\hline 2.1.1. Material costs & 18.242 .720 & 17.451 .067 & 16.291 .515 & 15.757 .680 & 15.388 .370 \\
\hline 2.1.2. Depreciation & 3.282 .869 & 3.282 .869 & 3.282 .869 & 3.282 .869 & 3.282 .869 \\
\hline 2.1.3. Gross salaries & 11.723 .439 & 11.723 .439 & 11.723 .439 & 11.723 .439 & 11.723 .439 \\
\hline 2.2. Financial expenses & - & - & - & - & - \\
\hline 3. Gross profit/loss (1.- 2.) & 5.953 .184 & 6.893 .338 & 8.204 .904 & 9.112 .942 & 9.905 .577 \\
\hline 4. Tax & - & - & - & - & - \\
\hline 5. Net profit (3.-4.) & - & - & - & - & - \\
\hline 5.1. Reserves & - & - & - & - & - \\
\hline 5.2. Share for owners in net profit & - & - & - & - & - \\
\hline 5.3. Retained profit & - & - & - & - & - \\
\hline
\end{tabular}

\section{Source: Authors calculation}

An insight into Profit and Loss Account shows that the income in the valuation period does not cover for the business costs, so there is loss in business for all years ranging from $5.953 .184 \mathrm{kn}$ to $9.905 .577 \mathrm{kn}$ for the last valuation period. Such a big loss is firstly the result of big material business costs and big amounts of gross salaries. While material costs are variable and their amounts decrease as the production volume decreases, gross salaries are fixed and represent constant burden for smaller production volume. Rather intense production and engagement of large number of workers are one of the causes of big gross salaries costs. From information from Profit \& Loss Account it can be concluded that business is in deficit during the entire valuation period, and that the coun- 
try does not levy taxes and the owners cannot expect share of profit. Coverage for loss is impossible with this kind of production volume as it is realized in all years with a tendency to increase in future. Next methodological step in DCF valuation is creating a Cash Flow which represents specific financial statement on future business by which the effect of all engaged firm's resources is measured. Namely, the firm disposes of all working and non - working capital and uses them to realize planned impacts.

TABLE 5: Cash Flow for the Period $1999-2003$

\begin{tabular}{|c|c|c|c|c|c|}
\hline Item / Year & 1999. & 2000. & 2001. & 2002. & 2003. \\
\hline I Income & $35,140.536$ & $25,564.036$ & $23,092.919$ & $21,651.046$ & $85,218.000$ \\
\hline 1. Total income & 27.295 .843 & $25,564.036$ & $23,092.919$ & $21,651.046$ & $20,489.101$ \\
\hline 2. Existing receivables & $5,298.213$ & - & - & - & - \\
\hline 3. Active money & $2,546.480$ & - & - & - & - \\
\hline 4. Residual value & - & - & - & - & $64,730.037$ \\
\hline 4.1. Capital assets & - & - & - & - & $45,590.604$ \\
\hline 4.2. Working capital & - & - & - & - & $19,139.433$ \\
\hline 4.3. Reserves & - & - & - & - & - \\
\hline II Expenditures & $33,956.655$ & $29,174.506$ & $28,014.954$ & $27,481.119$ & $27,111.809$ \\
\hline 5. Current liabilities & $3,990.496$ & - & - & - & - \\
\hline 6. Material costs & $18,242.720$ & $17,451.067$ & $16,291.515$ & $15,757.680$ & $15,388.370$ \\
\hline 7. Gross salaries & $11,723.439$ & $11,723.439$ & $11,723.439$ & $11,723.439$ & $11,723.439$ \\
\hline 8. Financial costs & - & - & - & - & - \\
\hline 9. Tax & - & - & - & - & - \\
\hline 10. Reserves & - & - & - & - & - \\
\hline $\begin{array}{l}\text { 11. Owners' share in net } \\
\text { profit }\end{array}$ & - & - & - & - & - \\
\hline III Net income & $1,183.881$ & $3,610.470$ & $4,922.035$ & $5,830.073$ & $58,106.191$ \\
\hline IV Discounted factors $(\mathrm{p}=12 \%)$ & 1,00 & 0,8929 & 0,7972 & 0,7118 & 0,6355 \\
\hline V Discounted value $\mathrm{NP}^{\mathrm{n}}$ & $1,183.881$ & $3,223.789$ & $3,923.846$ & $4,149.846$ & $36,926.484$ \\
\hline VI Present value & $24,445.122$ & & & & \\
\hline
\end{tabular}

Source: Authors calculation

Cash flow contains income, expenditures and net income. All items that increase economic potential of a firm in valuation period - total income, current and long-term receivables, existing money and residual value of firm - make an income. Since the discounted rate (p) of $12 \%$ was an average cost of the capital in the Croatian banking system at the time (1998 / 1999) and, taking into account an alternative use of capital, this average rate was taken as discount 
rate. By using relation (2) we got the firm's value as shown in the table 5 .

Despite the fact that the evaluated firm will realize more than 40 million kuna of gross loss of nominal value in the next five years, according to information from $\mathrm{P} \& \mathrm{~L}$ projection (Table 4), and despite relatively high discount rate, by applying DCF method and due to very high value of evaluated residual value of assets at the end of the fifth year of the observed period, for whose discounted value was increased a sum of discounted cash flows (Table 5), we get the present firm's value amounting 24,4 million kuna. Thus the firm which continually achieves negative business results, according to projections based on business flow, gains positive value when DCF method is applied. To simplify, let us assume that information from previous tables do not represent projections but the historical data from already realized business years and adjusted for inflation rates (Table 2). This assumption will enable the demonstration of new suggested CCF method and it will operate with identical sizes in order to compare the results of applied valuation methods more reliably. The only difference from the information in the table 5 will be elimination of residual value evaluation in 2003 amounting 64.368.899 kuna. 
TABLE 6: Cash Flow 2

\begin{tabular}{|c|c|c|c|c|c|}
\hline Item / Year & 1999. & 2000. & 2001. & 2002. & 2003. \\
\hline I Income & $35,140.536$ & $25,564.036$ & $23,092.919$ & $21,651.046$ & $20,489.101$ \\
\hline 1. Total income & 27.295 .843 & $25,564.036$ & $23,092.919$ & $21,651.046$ & $20,489.101$ \\
\hline 2. Existing receivables & $5,298.213$ & - & - & - & - \\
\hline 3. Active money & $2,546.480$ & - & - & - & - \\
\hline 4. Residual value & - & - & - & - & - \\
\hline 4.1. Capital assets & - & - & - & - & 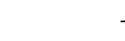 \\
\hline 4.2. Working capital & - & - & - & - & - \\
\hline 4.3. Reserves & - & - & - & - & - \\
\hline II Expenditures & $33,956.655$ & $29,174.506$ & $28,014.954$ & $27,481.119$ & $27,111.809$ \\
\hline 5. Current liabilities & $3,990.496$ & - & - & - & - \\
\hline 6. Material costs & $18,242.720$ & $17,451.067$ & $16,291.515$ & $15,757.680$ & $15,388.370$ \\
\hline 7. Gross salaries & $11,723.439$ & $11,723.439$ & $11,723.439$ & $11,723.439$ & $11,723.439$ \\
\hline 8. Financial costs & - & - & - & - & - \\
\hline 9. Tax & - & - & - & - & - \\
\hline 10. Reserves & - & - & - & - & - \\
\hline 11. Owners' share in net profit & - & - & - & - & - \\
\hline III Net income & $1,183.881$ & $3,610.470$ & $4,922.035$ & $5,830.073$ & 6,262708 \\
\hline IV Compounding factors. $(\mathrm{p}=12 \%)$ & 1,5735 & 1,4049 & 1,2544 & 1,1200 & 1,0000 \\
\hline $\mathrm{V}$ Value $\left(\mathrm{NP}^{\mathrm{n}}\right)$ & $1,862.860$ & $5,072.450$ & $6,262.009$ & $6,529.682$ & $6,262.708$ \\
\hline VI Present value II & $19,727.001$ & & & & \\
\hline
\end{tabular}

\section{Source: Authors calculation}

By applying the CCF method in accordance to the relation (??) with supposed discounted rate of $12 \%$ which is not equal to realized IRR (as it is meaningless to calculate it due to the negative net income), present value is expectedly negative.

Here is information interpretation and the result obtained from the Table 6 : by applying the CCF, net income was compounded in the period of five years (1999 - 2003) on "future" value regardless the negative results, i.e. losses. The sum of such net income represents present value (SvII) which is an expression 
of true and not projected economic potential of the firm. In this case it is a sum of business losses ( $\mathrm{Sv}$ II $=-19,7$ mil) meaning that the firm accumulated in five-year period such a sum of losses expressed in present value. In other words it is a "negative firm value". So, in difference to results obtained by DCF valuation method which demonstrates that firm is 24,4 million worth $(\mathrm{Sv}=24,4$ mil), the result of CCF method suggests completely opposite conclusion. In the CCF, information obtained from five-year Profit \& Loss Account are treated as realized results, and the final calculated value shows that the firm is not worth buying unless a new owner intends to invest in necessary reconstruction and reorganization, which is by far some other issue.

Syntagma "negative firm value" must not be confused with the negative price, and falsely concluded that the seller would have to pay the buyer for the firm. "Negative value" simply means that the valuated firm accumulated financial losses in the observed period. It does not mean that the firm has no potential ${ }^{7}$ which can be reflected on the price, moreover, it means that the method is based on realized results and not possible results whose realization demands certain organizational, human, investing and similar interventions. So, the CCF method considers the realized results on which it bases the value, and the price is completely other category subjected to different parameters and it does not need to correlate with the value. Anyway, the price (of certain thing) can at certain period of time be above or below the value (of that certain thing), so we can talk about overrating or underrating. The firm which realizes negative results in the observed period might have negative value (not price), as the price is the amount that the buyer is ready to pay and seller to accept. This paper deals with the issue of determining the value of certain business (firm).

Another characteristic of the CCF is that it does not calculate residual value because the method is based upon realized results, i.e. business effects which represent the base to value determination. Besides, "residual value" is the result

\footnotetext{
${ }^{7}$ The term „potentials" means "the unused option" and thus defined:

$\mathrm{e}(\max )-\mathrm{e}(\mathrm{p})=\mathrm{I}(\mathrm{p})$, where potential, measured by the degree of business efficiency, is equal to difference of maximal and obtained degree of efficiency. For different definition of the term "potential" and "economy potential", consult: Dragičević A.: "Ekonomski leksikon "-Informator Zgb. 1991; pp.163. and pp. 569. also see: www.thefreedictionary.com/economic+potential
} 
of balance sheet i.e. static valuation, thus having more the characteristic of liquidation value of firm's assets. Since the CCF values financial results realized in a certain period of time and it indirectly measures firm's potential, it would be wrong to correct such a value for residual value, methodologically speaking. Previous practical example nicely demonstrates the impact of the calculated residual value on the estimated value. It is completely clear that the CCF indicates to the fact that the firm is completely inefficient and that only the physical assets has liquidation value. So, the firm is seriously threatened by the possible production break or reorientation of its business which demands new investments, which is the subject of some new analysis and valuation.

\section{INSTEAD OF CONCLUSION: WHY THE CCF (Compounded Cash Flow)?}

The relation between the CCF valuation method of certain firm (business) and rather notorious DCF method can be clearly illustrated as in Fig. 2.

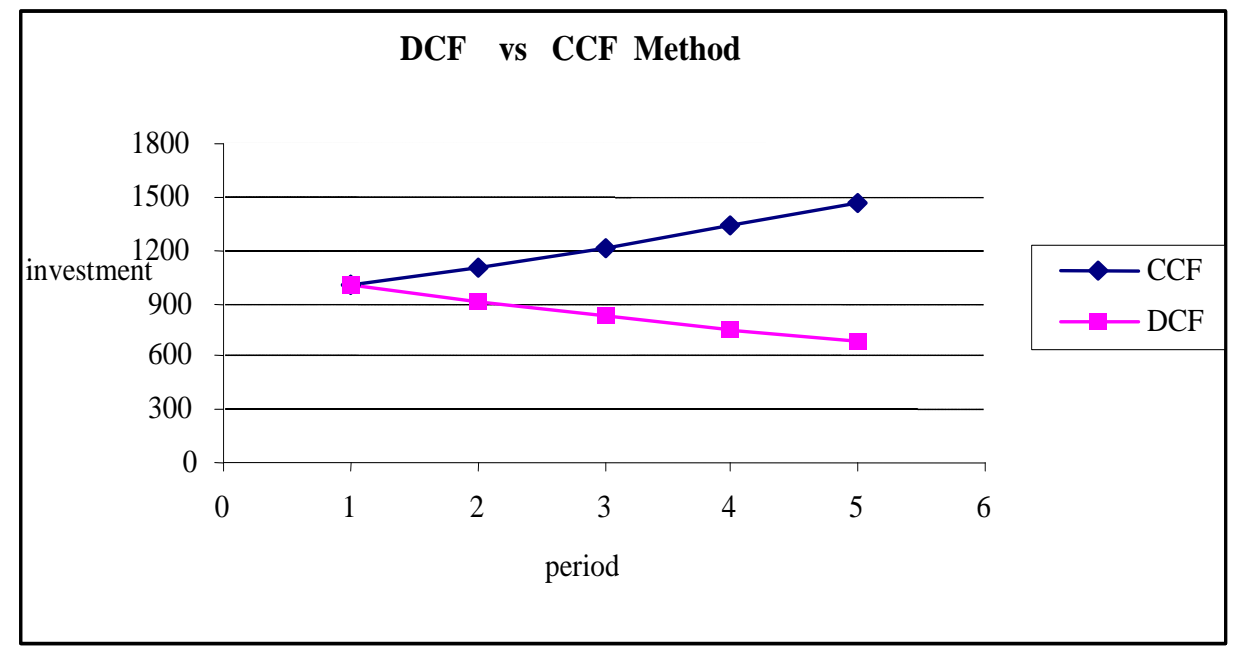

FIGURE. 2: Graphic Illustration of DCF and CCF Methods

Source: Authors calculation 
Two sides of one medal, compounding and discounting, when observed from mathematical point of view, are related by number of periods and interest rates, i.e. discounted rates. Observing the problem in the means of functions, the mentioned methods which are based on discounting, i.e. compounded are inverse functions.

Operating with historical and real information obtained from the firm's financial statements which reflect business events, in difference to using projections of the statement which are more or less subjected to different manipulations would be the biggest advantage of CCF method. Besides, as the method relies on historical database, the adjustments of those information (deflation, determination of market values of balance sheet items) are considered more reliable, being known and publicly available (information on inflation rates, market prices and similar). The compounding rate in this method is IRR (Internal Rate of Return), i.e. TRR (True Rate of Return), actually the average rate at which the invested money in certain business (investment) is compounded, and in this case the firm's valuation is observed as valuation of possible investment into some business (firm). So, the CCF method evaluates real business results and those firms with better financial results within longer period are much more highly ranked. Thus, when using the CCF it is recommendable to consider longer period of time and the length depends on an individual valuation and firm. Anyway, there is no unique valuation method which can be equally valuable in all valuation cases. Basic advantages of CCF method are: reliability, accuracy, confidentiality of information, basing the firm's present value on realized business effects, looking at the realized effects as the results of material, organizational, human and other factors. Withal, this method corresponds very well with EVA (Economic Value Added) as a metric of economic profit, i.e. firm's success and worthiness, and is defined like this:

$E V A=E B I T$ (Profit Prior to Interest Rate and Tax Deduction) - Cost of Capital

It is clear that proposed CCF method is actually dynamized ( $\sum \mathrm{CF}$, i.e. $\sum$ EBIT) and somewhat adapted IRR, i.e. TRR instead of cost of capital, i.e. WACC. 
It has already been emphasized that CCF valuation method does not consider residual value at the end of the observed period because this method measures firm's business potential (investment) with assumption business as usual. Introducing assets value or "residual value" would suppose certain methodological and conceptual confusion. Finally, in difference to CCF method, the DCF belongs to the part of economic models which are based upon projections, i.e. certain assumed relations in future. All obstacles, limitations and possible consequences of mistakes of such models and their procedures are elaborated in research work "Economic Methodology" by S. C. Dow. ${ }^{8}$

This work does not suggest elimination of former method(s), on the contrary, it suggests a new one as alternative or corrective.

This method, just like the others, has its advantages and limitations and it is very important to know when and how to use it: CCF is appropriate for firm's valuation from the potential buyer's point of view. Why? As it has already been shown and explained in the Fig. 2, the CCF represents inverse method of DCF. Namely, DCF is based on business plan, on possible future business and other accomplishments and values which are then discounted and thus given present value. In other words, future business events are "brought" into present. The CCF uses past, accomplished events and seizes that are easy to examine and revise. Such values reflect real firm's (business) potentials, moreover, they can be adjusted and made more real because we are familiar with past parameters (such as inflation rate and similar). Those sizes are then compounded and reduced to present value. That is why this valuation method could be called "regressive dynamic method". So, instead of travelling to future (and who can say for sure what will happen?), the CCF recommends travelling to familiar past.

The basic question (for buyers) is: do I buy the firm (business) basing on what it has been doing so far or basing on the assumptions what and how it will do business in future? What gives more realistic picture?

\footnotetext{
${ }^{8}$ Dow S.C.: „Ekonomska metodologija“ - Politička kultura, Zagreb, 2005. Author is dealing with the problem in details in the chapter 4 (pp.45-58); on reliability of forecasts of firm's business in the means of contemporary technological changes. Consult: The Economist, Feb.12-18, 2011,pp.11;69-71.
} 
To resume, as previously illustrated in Fig. 1, CCF gives present values by compounding realized sizes, just like bank investment, while DCF gives present values of more or less based promises.

The question: which method suits the buyer more, and which one the seller?

By using efficient combination of both methods, and starting from defining the term "potential" as it is defined in note number 7, the value of firm's (business) potential could be achieved because CFF measures realized efficacy, while DCF measures future maximal business potentials. ${ }^{9}$

The intention is to offer appraisals another helpful method, another possibility to consider the problem of determining value of certain firm, business and investment. The corrective role of the CCF method should be specially emphasized because appraisals would be "forced" to thoroughly explain possible big discrepancy between the results of the DCF and CCF for the same firm (business) and it should slightly eliminate insider information. The basic concept of the CCF is coherent to investment philosophy of B. Graham and W.Buffett (and similar investors) ${ }^{10}$ who were, and W.Buffett still is, advocates of basic and reliable fundamental analysis of each investment, i.e. purchase, whether those are securities, concrete firm or real estate.

\footnotetext{
${ }^{9}$ It is interesting that very often in their business plans, firms plan significant improvements in business, production, placement, efficiency and similar. Comparing them with their financial statements of the previous period, you get the impression it is not the same firm.

${ }^{10}$ Consult: Graham B.: „Inteligentni investitor"- Masmedia, Zagreb, 2006 ; also consult: Hagstrom R.G.: „Buffettova načela“- Katarina Zrinski d.o.o., Varaždin, 2008.; also: Jain P.C.: „Buffett Beyond Value“- Wiley Inc., N.J. USA, 2010.
} 


\section{References}

Bendekovic-Lasic-Brozovic-Jancin: "Procjena pravnih osoba,imovine i obveza"/metodološki prilozi/ - FOIP Zagreb, 1998.

Bodie-Kane-Marcus: „Pocela ulaganja“ (IV edition)) - Mate d.o.o. Zagreb, 2006.

Chiang A.C. : "Osnovne metode matematicke ekonomije" (III edition)Mate d.o.o. Zagreb, 1994.

Damodaran A.: "Damodaran o valuaciji“" (II edition) - Mate d.o.o. Zagreb, 2010.

Dow S.C: „Ekonomska metodologija“ - Politicka kultura Zagreb, 2005.

Dragicevic A.:"Ekonomski leksikon"- Informator Zagreb, 1991.

Graham B.: „Inteligentni investitor“- Masmedia Zagreb, 2006.

Hagstrom R.G.: „Buffettova nacela“- Katarina Zrinski d.o.o. Varaždin, 2008 .

Jain P.C.: „Buffett Beyond Value“ - Wiley Inc., N.J., USA, 2010.

Martic Lj.: "Kvantitativne metode za financijske i racunovodstvene analize"Informator, Zagreb, 1980.

Nušinovic M.: „Planiranje investicijskih projekata u funkciji optimizacije društveno-ekonomskog razvoja" - Ekonomski institut - Zagreb, 1989.

Pike-Neal: "Corporate Finance \& Investment" - Prentice Hall Int. (UK) Hempstead, 1993.

Viducic Lj.: „Financijski menadžment“ (II edition) - RRIF Zagreb, 2001. The Economiat, February 12th-18th 2011. pp.11; 69-71.

www.hnb.hr/public/prezent/spf-cro-ppt_

www.thefreedictionary.com/economic+potential

_www.sjsu.edu/faculty/watkins/countryrisk.htm

www.sternn.yu.edu/-adomodar/pc/cf2Eil 


\section{PROCJENA TVRTKE - NOVI METODOLOŠKI PRISTUP \\ Sažetak}

Procjenu vrijednosti nekog poduzéca moguće je odrediti na više načina, a najčešca metoda je metoda diskontiranih novčanih tokova (DCF).Spomenuta metoda ima dvije osnovne karakteristike: vodi računa o vremenskoj preferenciji novca i promatra vrijednost poduzéca (posla) kao zbir mogućih budućih neto prihoda.Dakle,sadašnju vrijednost ova metoda temelji na eventualnim budućim neto prihodima diskontiranim po diskrecijskoj diskontnoj stopi. Nasuprot tome, u ovom radu opisana CCF (Compounded Cash Flow) metoda procjene se bazira na povijesnim podacima iz financijskih izvješća i na poznatim i javno dostupnim parametrima za ispravke bilančnih stavki i deflacioniranje novčanih tijekova. $\mathrm{Na}$ taj način se postiže pouzdanija i vjerodostojnija procjena vrijednosti poduzeća koja se temelji na realnim vrijednostima.

Ključne riječi: procjena ; vrijednost; DCF, CCF; metoda, ulaganje; financijska izvješća 